\title{
Planting Depth Affects Root Form of Three Shade Tree Cultivars in Containers
}

\author{
Edward F. Gilman, Chris Harchick, and Maria Paz
}

\begin{abstract}
Study was designed to evaluate impact of planting depth on root morphology inside nursery containers. Trees were planted shallow (13 $\mathrm{mm})$ or deep $(64 \mathrm{~mm})$ into \#3 Air-Pot ${ }^{\mathrm{TM}}$ containers, then shallow $(0 \mathrm{~mm})$ or deep $(64 \mathrm{~mm})$ into \#15 containers prior to shifting them to their final \#45 container size at the same depth. Trunk diameter (caliper) was significantly larger for both magnolia and maple planted shallow (13 $\mathrm{mm})$ into \#3, and then shallow into \#15 containers when compared to planting deeper. However, differences were small and may not be relevant to a grower. No caliper or height differences among planting depths were found for elm. Presence of stem girdling roots in elm and magnolia growing in \#45 containers increased with planting depth into \# 3 containers. Downward re-orientation of main roots comprising the flare by \#3 container wall, likely contributed to amount of roots growing over root flare. Maple root systems were not impacted by planting depth into \#3 primarily due to adventitious root emergence from the buried portion of stem. Distance between substrate surface and top of root flare in finished \#45 containers was not impacted by planting depth into \#3 containers for any species. Planting elm and maple deeply into \#15 led to more trunk-girdling by roots, a deeper root flare, and more roots growing over flare compared to planting shallow. Most root defects in all species were hidden from view because they were found below substrate surface. Presence of a visible root flare was not related to occurrence of root defects. Root balls on elm and maple were packed with roots which made it time consuming to remove substrate and roots above the root flare. Planting depth appears most crucial when shifting into \#15 containers.

Key Words. Adventitious Roots; Circling Roots; Deflected Roots; Descending Roots; Root Defects; Root Flare; Stem Girdling Roots.
\end{abstract}

Reasons suggested for planting trees below grade in field soil include increased stability (Lyons et al. 1987), increased moisture for establishing trees (Koshi 1960; VanderSchaaf and South 2003), simpler mechanical planting of forestry plots (Slocum and Maki 1956; Harrington and Howell 1998), reduced damage from herbicide (Reighard et al. 1985), reduced sprouting, and hiding the graft union on grafted trees (Watson 2005). Most research on planting depth was conducted on young seed-propagated seedlings (SP) planted into soil in commercial forestry operations.

Cutting propagated (CP) root systems differ from SP because cuttings lack a tap root (Goldfarb et al. 1998). Some CP trees generate roots primarily from the end of the cut stem (e.g., Magnolia grandiflora); whereas Pinus (Goldfarb et al. 1998), and others such as red maple produce roots along the buried part of the stem. Red maple can produce more than 60 first order lateral roots along a four centimeter buried portion of the stem under ideal conditions (Gilman unpublished); whereas some trees such as oaks may only produce one under poor propagation conditions. Many of these grow down at an angle. Increased number of primary lateral roots growing from the taproot on SP has been associated with good field performance after planting (Kormanik 1986) but there are few studies on CP trees. Seeds are typically placed on or only partially into the top surface of substrate. Stems of CP trees are inserted a few $\mathrm{cm}$ into substrate.

One of the reasons for unfavorable growth of some deeply planted SP trees is a tendency for roots to circle, bend, or otherwise become deformed (Seiler et al. 1990). Harrington and How- ell (1998) found that growth of Pinus taeda was significantly greater when trees were planted with straight roots rather than deformed or pruned taproots. In contrast, Seiler et al. (1990) found that Pinus taeda and Pinus strobus with J-roots did not show reduced growth or increased water stress after three years when they were planted with the root collar at grade. After five years, Carvell and Kulow (1964) found an upper layer of superficial roots had formed on Pinus strobus trees planted 15.2 $\mathrm{cm}$ below grade and original roots were growing up toward the soil surface. Sparks (2005) found after three years, weakly developed lateral or brace roots on deeply planted Carya illinoinensis trees resulted in increased tilting or blowing over during a hurricane. Lyons et al. (1983) found that after two years, Malus domestica were less likely to be shaken loose by wind when planted at the same depth as they were in the nursery than when planted up to $20 \mathrm{~cm}$ deeper than they were in the nursery.

Few have studied planting depth or root morphology in large containers. After one year in above-ground containers, height of Cornus florida was significantly less on trees that were planted deeply compared to shallow (Browne and Tilt 1992; Fare 2005). Caliper of Cornus florida was greatest when planted shallow. Caliper was reduced when trees were planted $10 \mathrm{~cm}$ or $15 \mathrm{~cm}$ deep. One year after planting in containers, survival of Acer rubrum and Pinus virginiana was reduced when planted at the same depth as they were in the nursery or $15 \mathrm{~cm}$ deeper; trees planted at $5 \mathrm{~cm}$ or $10 \mathrm{~cm}$ deep had the greatest survival. Root defects from deep planting in containers have rarely been de- 
scribed. Liners of Cathedral Oak ${ }^{\circledR}$ live oak planted deeply into \#3 Accelerator ${ }^{\circledR}$ (Nursery Supplies Inc., Chambersburg, PA) containers generated some circling roots over the root flare which reduced their quality (Gilman et al. 2006). However, quality was reduced most when \#3 trees were planted deeply into \#15 sized containers because trees apparently lost their capacity to generate adventitious roots along the buried portion of the trunk. Fare (2005) presented photographs showing that red maple planted deeply into \#3 smooth sided containers had many roots growing over the root flare compared to trees planted shallower.

The objective of this study was to measure stem girdling root formation, root length over root flare, depth of the flare, and trunk growth resulting from different planting depths when shifting from one nursery container size to the next for producing $6 \mathrm{~cm}$ caliper (trunk diameter) landscape sized trees.

\section{MATERIALS AND METHODS}

In June 2005, 104 stem cuttings of Magnolia grandiflora MISS $\mathrm{CHLOE}^{\circledR}$ rooted in square $6.9 \mathrm{~cm}$ across $\times 14 \mathrm{~cm}$ deep smoothsided containers, and Acer rubrum L. 'Florida Flame' and $\mathrm{Ul}$ mus parvifolia Allée ${ }^{\circledR}$ rooted in circular $55 \mathrm{~mm}$ diameter $\times$ $130 \mathrm{~mm}$ deep smooth-sided cones were planted into \#3 $(27 \mathrm{~cm}$ across top and bottom, $20 \mathrm{~cm}$ deep) Air-Pot ${ }^{\mathrm{TM}}$ cylindrical black plastic containers (Caledonian Tree Company, Ltd., Scotland). The plot was located in USDA hardiness zone $8 \mathrm{~b}$ in Gainesville, FL. Magnolia roots originated primarily near the end of the cutting; whereas, roots on maples and elms emerged near the end and from along the buried stem. The point where the topmost root emerged from stem was placed either $13 \mathrm{~mm}$ (shallow) or $64 \mathrm{~mm}$ (deep) below \#3 substrate surface by removing an appropriate amount of substrate from top of liner root ball.

Trees in \#3 containers were spaced pot-to-pot (i.e., touching one another) except for a $1.8 \mathrm{~m}$ walk row every four rows. Trees were irrigated 2 or 3 times daily totaling $3.8 \mathrm{~L}$ through one Roberts (Roberts Irrigation Products, Inc. San Marcos, ID) Spot-Spitter per container until autumn 2005, when irrigation frequency and volume was reduced. In late January 2006, all trees were shifted into \#15 (47 cm across top and bottom, $30 \mathrm{~cm}$ deep) containers, whereby half the trees of all species $\times \# 3$ planting depths were positioned shallow (\#3 substrate surface even with \#15 substrate surface) or deep (\#3 substrate surface $64 \mathrm{~mm}$ below \#15 substrate surface). A total of four planting depth combinations resulted from the two planting sessions: 1) $13 \mathrm{~mm}$ deep into \#3, $0 \mathrm{~mm}$ deep into \#15; 2) $64 \mathrm{~mm}$ deep into \#3, $0 \mathrm{~mm}$ deep into \#15; 3) $13 \mathrm{~mm}$ deep into \#3, $64 \mathrm{~mm}$ deep into \#15; and 4) $64 \mathrm{~mm}$ deep into \#3, $64 \mathrm{~mm}$ deep into \#15. No roots were pruned or mechanically manipulated in any way at any time during the study.

Trees in \#15 containers were spaced $2.4 \mathrm{~m}$ apart and irrigated three times daily in the growing season (weather dictating), with a maximum $15 \mathrm{~L}$ through two Roberts Spot-Spitters. In February 2007, all trees were shifted into \#45 (75 cm across top, $61 \mathrm{~cm}$ across bottom, $48 \mathrm{~cm}$ deep) round smooth-sided black plastic containers (Nursery Supplies, Inc., Chambersburg, PA) with \#15 substrate surface even with \#45 substrate surface on all trees. Trees remained $2.4 \mathrm{~m}$ apart and were irrigated two to three times daily in the growing season with a maximum $45 \mathrm{~L}$ through three Roberts Spot-Spitters until October, when volume was dropped to $15 \mathrm{~L}$ daily or less frequently as weather dictated. Elm and maple shoots were pruned and trunks staked in 2006 and 2007 to develop one leader, and to shorten and remove large lower branches creating a $1.5 \mathrm{~m}$ trunk clear of branches. Magnolias were pruned only to maintain a central dominant leader. Trees were secured to a trellis system for stability in wind.

Substrate was 50:40:10 (New Florida peat: pine bark: sand, volume). New Florida peat is a compost of Florida peat and hardwood bark fines (Florida Potting Soil, Inc., Orlando, FL). Fertilizer (18-5-10 controlled release, Harrells Inc., Lakeland FL) was incorporated into substrate prior to planting at $10.74 \mathrm{~kg} / \mathrm{m}^{3}$, and no other fertilizer was applied. Weeds were periodically pulled from container substrate. Excepting some elms, trees did not root out of pots and into ground.

In September 2007, root flare (point where main roots emerged from trunk) was evaluated as visible at the substrate surface or not visible on all trees. Trees were graded as cull or not according to Florida Grades and Standards for Nursery Stock (Anonymous 1998), prior to any substrate removal. A cull rating was given to trees with one or more roots larger than onetenth trunk diameter (measured $15 \mathrm{~cm}$ from ground) that together circled more than one-third around the circumference of trunk. Five blocks of each cultivar (20 trees total for each cultivar) were randomly selected for removing the top $15 \mathrm{~cm}$ of substrate from root ball using a strong stream of air from an AirKnife ${ }^{\circledR}$. Trees were graded as cull or not following removal of substrate.

The outside edge of the \#15 container was used as a form to paint a circle centered on the trunk on \#45 substrate surface. Roots greater than $5 \mathrm{~mm}$ diameter in the painted circle that grew over the root flare were removed and their length measured. Trunk circumference was measured at substrate surface just above any swelling associated with the flare as was length of any root segment greater than $5 \mathrm{~mm}$ diameter that rested against the trunk over the flare [these were designated stem girdling roots (SGRs)]. SGR length was totaled and the percent of trunk circumference with SGRs was calculated; if more than one root was touching at the same point only one was measured. This provided the percentage of trunk circumference with a SGR in contact with the trunk. The study authors measured the distance between substrate surface and the part of the root flare $8 \mathrm{~cm}$ from the trunk closest to substrate surface. The largest diameter three main roots emerging directly from trunk were rated as deflected by the liner and/or \#3 container wall or not deflected. Caliper (trunk diameter $15 \mathrm{~cm}$ from ground) and tree height were measured annually on all trees.

Cultivars were arranged in their own randomized complete block design with four trees, one from each planting depth combination, in each of 26 blocks. Cultivar blocks were adjacent to one another. Analysis of variance in the GLM procedure within SAS (SAS Institute, Cary, NC) was used to evaluate impact of main effects and interactions on measured parameters. The two main effects were planting depth into \#3 containers and planting depth into \#15. Each main effect had two levels, shallow and deep planting. Percent trees with visible root flare at substrate surface, or those evaluated as culls prior to and after substrate removal were analyzed with two-way ANOVA using GENMOD procedure in SAS.

\section{RESULTS}

\section{Crown Growth}

Caliper of finished trees in \#45 containers was significantly larger for both magnolia and maple planted shallow (13 $\mathrm{mm}$ below 
grade) into \#3 containers (data not shown) or shallow (at grade) into \#15 containers (Table 1), when compared to planting deeply for both container sizes. However, differences were small and may not be relevant to a tree grower. Height of magnolia and elm was not affected by planting depth into \#3 (data not shown) or into \#15 (Table 1). Height of maple trees planted shallow was greater $(P=0.08)$ than for trees planted deeply into \#15 container. No caliper differences among planting depths were found for elm.

\section{Root Form}

Presence of root deflections in elm and magnolia growing in \#45 containers was influenced by planting depth into \# 3 Air-Pot (Table 2). Planting magnolia rooted cuttings $64 \mathrm{~mm}$ deep into \#3 containers resulted in more than double (compared to $13 \mathrm{~mm}$ planting

Table 1. Caliper and height of MISS CHLOE magnolia, 'Florida Flame' maple, and Allée elm growing in \#45 smooth sided containers after planting at two depths into \#15 Air-Pot containers.

\begin{tabular}{lccc}
\hline Cultivar & $\begin{array}{c}\text { Planting depth } \\
\text { into \#15 }(\mathrm{mm})\end{array}$ & Caliper $(\mathrm{cm})$ & Height $(\mathrm{m})$ \\
\hline Magnolia & 0 & $5.6 \mathrm{a}^{\mathrm{y}}$ & 3.00 \\
& 64 & $5.3 \mathrm{~b}$ & 2.98 \\
Maple & 0 & $6.8 \mathrm{a}$ & $5.13 \mathrm{a}^{\mathrm{x}}$ \\
& 64 & $6.5 \mathrm{~b}$ & $4.98 \mathrm{~b}$ \\
Elm & 0 & 6.0 & 4.66 \\
& 64 & 6.0 & 4.62 \\
\hline
\end{tabular}

${ }^{\mathrm{z}}$ Planting depth when \#3 root balls were shifted into \#15 Air-Pot containers. All finished \#15 root balls were shifted into \#45 containers with top of root ball even with substrate surface. Means of 52 trees per planting depth averaged across \#3 container planting depths due to insignificant interaction.

${ }^{y}$ Means in a column for each cultivar with a different letter are statistically different at $P<0.01$.

${ }^{x}$ Means in a column for each cultivar with a different letter are statistically different at $P=0.08$. depth) the percent of trunk circumference with SGRs, total length of roots greater than $5 \mathrm{~mm}$ diameter growing over the flare, and roots 5-10 mm diameter growing over flare in \#45 containers (Table 2). Planting elm rooted cuttings $64 \mathrm{~mm}$ deep into \#3 containers resulted in greater trunk circumference girdled with roots $(69 \%)$ compared to $13 \mathrm{~mm}$ planting depth $(36.1 \%)$, but planting depth had no impact on length of roots growing over the flare (Table 2). Distance between substrate surface and top of root flare was not impacted by planting depth into \#3 containers for any cultivar. Maple root systems were not impacted by planting depth into \#3.

Although maple planting depth into \#3 containers had no impact on any measured root parameter, planting maple deeply into \#15 containers led to more trunk girdling, a deeper root flare, and more roots growing over the flare (Table 2). More than two-thirds of trunk circumference of maple and elm was in direct contact with bark of SGRs on trees planted deeply into \#15 Air-Pots compared to just over one-third for trees planted even with substrate surface. In contrast to what occurred when planting magnolia deeply into \#3, percent trunk girdled and root length over flare was not impacted by planting depth into \#15. Trees of all cultivars planted deeply $(64 \mathrm{~mm})$ into \#15 containers had a deeper root flare than trees planted even with substrate.

\section{Root Flare Characteristics}

Interaction between planting depth into \#3 and depth into \#15 was significant for visible root flare (Table 3 ). The result was that more magnolia planted shallow into both container sizes had a visible root flare (74.1\% of trees) compared to other combinations of planting depth $(0 \%-16 \%)$. Root flare visibility on elm and maple was not impacted by planting depth into \#3 containers, but both species had more visible root flares when planted shallow into \#15 than deep. Interaction between \#3 and \#15 planting depths was significant for elm and maple. The result was maple planted deeply into both container sizes had less visible root flare than those planted deep into \#3 then shallow into

Table 2. Effect of planting depth into either \#3 or \#15 Air-Pot containers on subsequent root form of MISS CHLOE magnolia, 'Florida Flame' maple and Allée elm growing in \#45 smooth-sided containers².

\begin{tabular}{|c|c|c|c|c|c|}
\hline Cultivar & $\begin{array}{l}\text { Planting depth } \\
\text { into \#3 (mm) }\end{array}$ & $\begin{array}{l}\% \text { of trunk } \\
\text { circumference } \\
\text { girdled }^{y}\end{array}$ & $\begin{array}{l}\text { Depth to root flare } \\
\qquad(\mathrm{cm})\end{array}$ & $\begin{array}{l}\text { Total root length } \\
\text { growing over } \\
\text { root flare }(\mathrm{cm})\end{array}$ & $\begin{array}{l}\text { Root length }(5-10 \mathrm{~mm} \\
\text { diameter) growing over } \\
\text { root flare }(\mathrm{cm})\end{array}$ \\
\hline \multirow[t]{2}{*}{ Magnolia } & 13 & $13.4 b^{w}$ & 6.8 & $37.8 b^{u}$ & $18.4 b^{v}$ \\
\hline & 64 & $32.6 \mathrm{a}$ & 8.2 & $76.3 \mathrm{a}$ & $52.3 \mathrm{a}$ \\
\hline \multirow[t]{2}{*}{ Elm } & 13 & $36.1 b^{v}$ & 8.0 & 92.4 & 80.1 \\
\hline & 64 & $69.0 \mathrm{a}$ & 9.1 & 127.0 & 108.4 \\
\hline \multirow[t]{2}{*}{ Maple } & 13 & 59.9 & 5.6 & 346.5 & 266.0 \\
\hline & 64 & 58.2 & 5.2 & 420.5 & 328.7 \\
\hline Cultivar & $\begin{array}{l}\text { Planting depth } \\
\text { into \#15 (mm) }\end{array}$ & $\begin{array}{l}\% \text { of trunk } \\
\text { circumference } \\
\text { girdled }^{\mathrm{y}}\end{array}$ & $\begin{array}{l}\text { Depth to root flare } \\
\qquad(\mathrm{cm})\end{array}$ & $\begin{array}{l}\text { Total root length } \\
\text { growing over } \\
\text { root flare }(\mathrm{cm})\end{array}$ & $\begin{array}{l}\text { Root length }(5-10 \mathrm{~mm} \\
\text { diameter) growing over } \\
\text { root flare }(\mathrm{cm})\end{array}$ \\
\hline \multirow[t]{2}{*}{ Magnolia } & 0 & 6.7 & $6.2 \mathrm{~b}^{\mathrm{u}}$ & 33.8 & 31.8 \\
\hline & 64 & 14.3 & $8.9 a$ & 49.2 & 39.0 \\
\hline \multirow[t]{2}{*}{ Elm } & 0 & $36.4 b^{v}$ & $7.0 b^{v}$ & $75.9 b^{v}$ & $62.9 b^{u}$ \\
\hline & 64 & $68.6 \mathrm{a}$ & $10.1 \mathrm{a}$ & $143.5 \mathrm{a}$ & $125.7 \mathrm{a}$ \\
\hline \multirow[t]{2}{*}{ Maple } & 0 & $41.0 \mathrm{~b}^{\mathrm{u}}$ & $4.2 b^{u}$ & $303.5 b^{v}$ & $233.6 b^{v}$ \\
\hline & 64 & $77.0 \mathrm{a}$ & $6.7 \mathrm{a}$ & $463.4 \mathrm{a}$ & $361.1 \mathrm{a}$ \\
\hline
\end{tabular}

${ }^{\mathrm{z}}$ All \#15 root balls were shifted with substrate surface even with \#45 substrate surface. Only roots $>5$ mm diameter were measured.

y Percent of trunk circumference with stem girdling roots $>5 \mathrm{~mm}$ diameter touching bark.

${ }^{x}$ Distance between substrate surface and point where top of first main lateral root emerged from trunk measured $8 \mathrm{~cm}$ from trunk.

${ }^{\text {w }}$ Means of a cultivar in a column with a different letter are different at $P=0.09$.

${ }^{v}$ Means of a cultivar in a column with a different letter are different at $P<0.05$.

${ }^{u}$ Means of a cultivar in a column with a different letter are different at $P<0.01$. 
\#15 containers. In addition, elm planted deeply into \#15 had less visible flare than those planted shallow, but only for trees planted shallow into \#3. In other words, visibility of root flare for elm planted deeply into \#3 and then again deeply into \#15 was similar to elm planted deeply into \#3 then shallow into \#15.

No magnolia or elm had enough roots circling the trunk that were visible at substrate surface to rate any tree a cull (Table $3)$. However, once substrate was washed from roots it was clear many trees were culls meaning that roots with a diameter greater than one-tenth the trunk caliper circled more than one-third around the trunk. Some maple trees were culls without substrate removed; however, all maples were rated as culls following substrate removal (Table 3; Figure 1). Elms planted deeply into \#15 containers were more likely to be culls than trees planted shallow, regardless of planting depth into \#3 containers. Presence of visible root flare prior to substrate removal was not related to actual cull rating following substrate removal (Table 3).

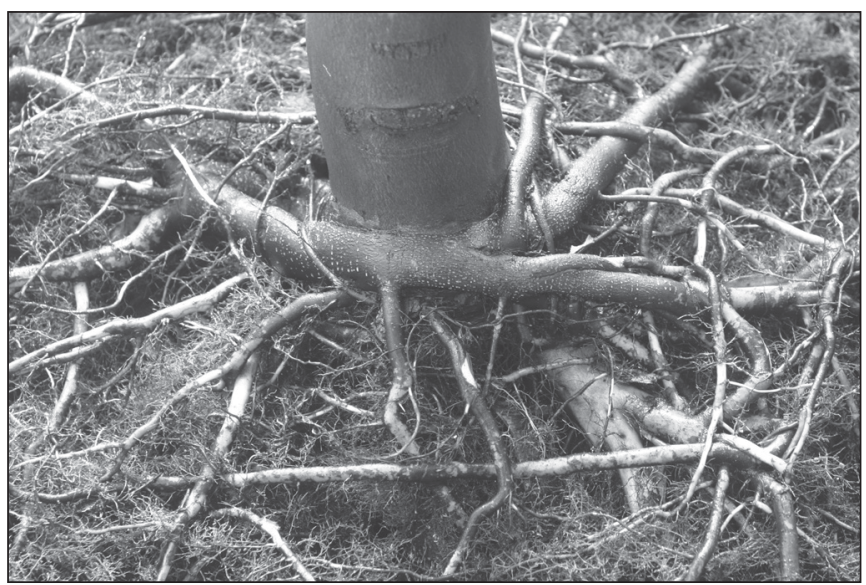

Figure 1. 'Florida Flame' red maple in \#45 container showing stem girdling roots hidden by substrate. Substrate surface was just above large SGR touching trunk.

\section{DISCUSSION}

\section{Main Lateral Roots And Root Flare}

Downward re-orientation of main roots comprising the flare by \#3 container wall probably contributed to the amount of roots growing over the root flare (Table 2) resulting in a large percentage of root systems grading as culls for all planting depths (Table 3). Deflection up and around container wall also encourages root growth over the flare (Gilman et al. 2010a). These deflected root forms are consistent with other studies (Balisky et al. 1995; Owen and Stoven 2008), but are different from root systems on trees in nature where many of the largest diameter roots orient more or less straight (Stout 1956; Balisky et al. 1995). Perhaps to reduce defects over the flare in containers, it is necessary to produce surface roots at a right angle to the trunk base early in propagation so main roots grow close to the substrate surface.

Deeper planting was associated with more roots growing over the root flare (magnolias into \#3, elm and maple into \#15; Table 2). Roots over the flare in \#45 containers originated from roots growing upward from the top surface of the liner and \#3 root balls into new substrate of the larger container, and from being redirected upward and around after meeting the liner and/
Table 3. Percent trees planted at two depths into \#3 and \#15 Air-Pot containers and finished in \#45 smooth sided containers $^{2}$ with visible root flare, visible root cull, and actual cull.

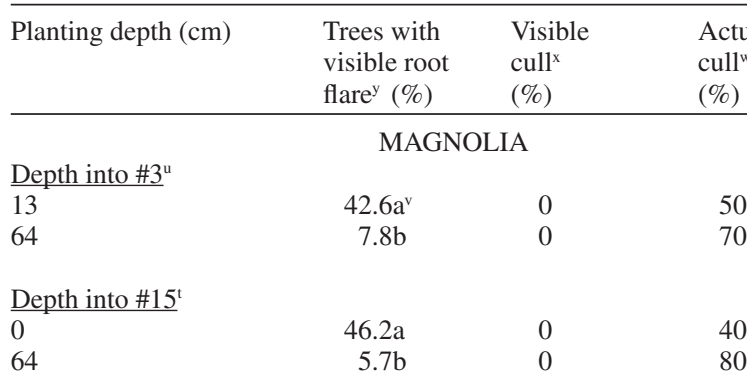

\begin{tabular}{lccll}
$\begin{array}{l}\text { Depth } \\
\text { into \#3 }\end{array}$ & $\begin{array}{c}\text { Depth } \\
\text { into \#15 }\end{array}$ & & & \\
\hline 13 & 0 & $74.1 \mathrm{a}$ & 0 & 20 \\
13 & 64 & $11.1 \mathrm{~b}$ & 0 & 80 \\
64 & 0 & $16.0 \mathrm{~b}$ & 0 & 60 \\
64 & 64 & $0.0 \mathrm{~b}$ & 0 & 80 \\
\hline
\end{tabular}

$\begin{array}{lrrr} & \text { ELM } & \\ \text { Depth into \#3 }^{\mathrm{u}} & & & \\ 13 & 22.5 & 0 & 80 \\ 64 & 15.8 & 0 & 80 \\ & & & \\ \text { Depth into \#15 }^{\mathrm{t}} & 28.9 \mathrm{a} & 0 & 60 \\ 0 & 9.5 \mathrm{~b} & 0 & 100\end{array}$

\begin{tabular}{lccll}
$\begin{array}{l}\text { Depth } \\
\text { into \#3 }\end{array}$ & $\begin{array}{c}\text { Depth } \\
\text { into \#15 }^{\text {s }}\end{array}$ & & & \\
13 & 0 & $41.7 \mathrm{a}$ & 0 & 60 \\
13 & 64 & $4.0 \mathrm{~b}$ & 0 & 100 \\
64 & 0 & $14.3 \mathrm{ab}$ & 0 & 60 \\
64 & 64 & $17.6 \mathrm{ab}$ & 0 & 100 \\
\hline
\end{tabular}

$\underline{\text { Depth into \#3 }}^{\text {u }}$

\begin{tabular}{|c|c|c|c|c|}
\hline 13 & & 68.5 & 24.1 & 100 \\
\hline 64 & & 63.5 & 32.7 & 100 \\
\hline Depth i & & & & \\
\hline 0 & & $79.3 \mathrm{a}$ & 28.3 & 100 \\
\hline 64 & & $52.8 b$ & 28.3 & 100 \\
\hline $\begin{array}{l}\text { Depth } \\
\text { into \#3 }\end{array}$ & $\begin{array}{c}\text { Depth } \\
\text { into \#15 }\end{array}$ & & & \\
\hline 13 & 0 & 77.8ab & 22.2 & 100 \\
\hline 13 & 64 & $59.3 \mathrm{ab}$ & 25.9 & 100 \\
\hline 64 & 0 & $80.8 \mathrm{a}$ & 34.6 & 100 \\
\hline 64 & 64 & $46.2 b$ & 30.8 & 100 \\
\hline
\end{tabular}

${ }^{\mathrm{z}}$ Container \#15 root balls were shifted with substrate surface even with \#45 substrate surface.

${ }^{y}$ Root flare visible at substrate surface.

${ }^{\mathrm{x}}$ Root system graded as cull prior to substrate removal based on Florida Grades and Standards for Nursery Stock (Anonymous 1998).

${ }^{w}$ Root system graded as cull following removal of top $15 \mathrm{~cm}$ of substrate

${ }^{v}$ Means of a cultivar in a column with a different letter are significantly different at $P<0.01$.

${ }^{u}$ Means of a cultivar of 52 (visible) or 10 (actual) trees per planting depth averaged across \#15 container planting depths.

${ }^{t}$ Means of a cultivar of 52 (visible) or 10 (actual) trees per planting depth averaged across \#3 container planting depths.

${ }^{\mathrm{s}}$ Means of a cultivar of 26 (visible) or 5 (actual) trees per planting depth combination.

or \#3 container walls (Figure 2). This also occurred for Acer rubrum in seven other container types (Fare 2005; Gilman et al. 2010a). Some redirection also occurred when roots met the \#15 container wall. Once redirected roots reached the substrate 
surface, they grew either along the wall or across the top of the root ball until they were again deflected by container wall. This upward root growth pattern is not common for trees in natural settings unless trees are positioned on slopes (Coutts and Nicoll 1991), and in that case growth is up at a much shallower angle. Roots on trees respond to their soil environment as soon as seeds germinate, so their form represents a continuum in response to soil environment in situ (Halter and Chanway 1993). This makes root reorientation unnecessary in many natural settings.

Live oak planted deeply into \#3, \#15, and \#45 Accelerator containers generated more deflected bent roots over the flare than those planted shallow (Gilman et al. 2006). Data presented in Table 2 show that increasing planting depth resulted in more roots over the flare for all cultivars tested. Many of these were growing from bent roots deflected by Air-Pot container wall. Straight lateral roots (Harrington and Howell 1998; Lindstrum and Rune 1999) combined with root plate symmetry (Coutts et al. 1999), are considered important components of tree stability, especially

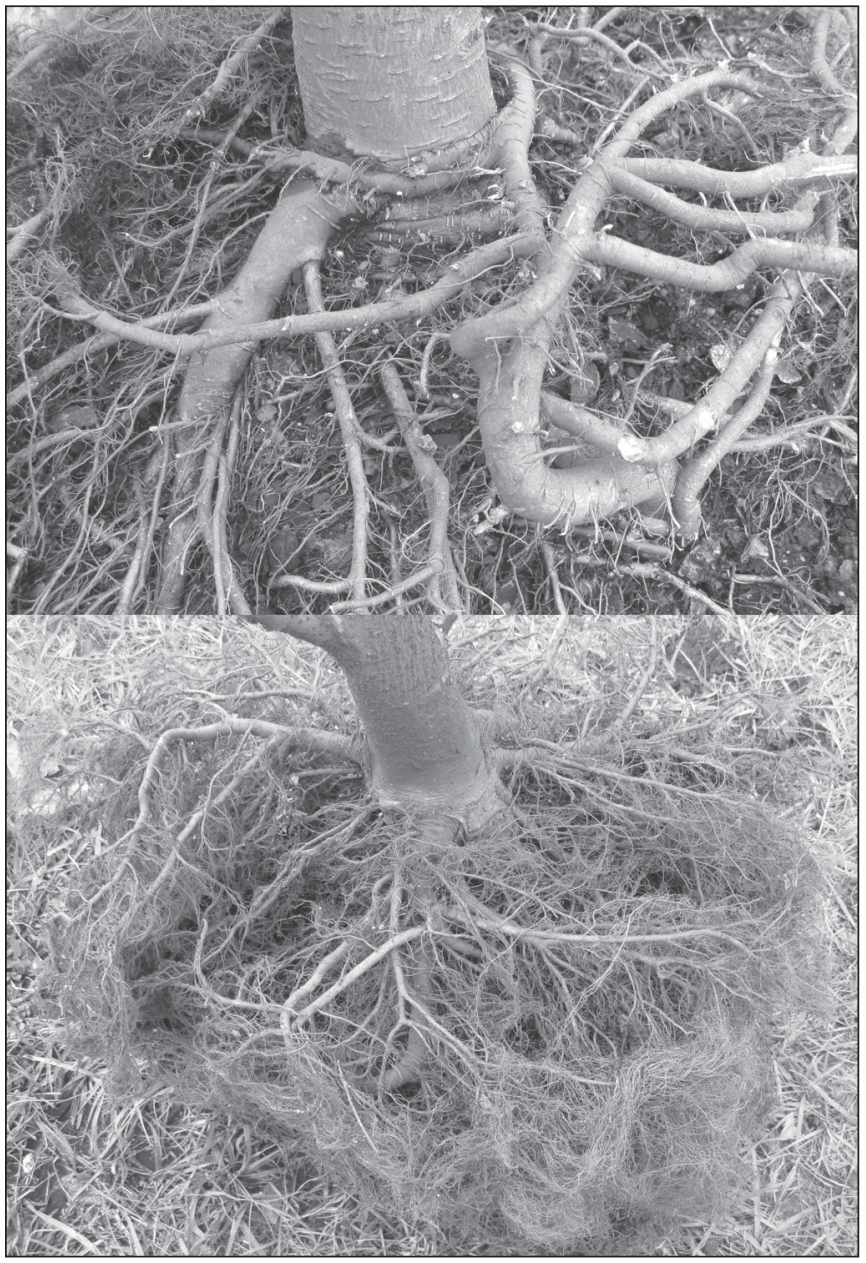

Figure 2. Top: Elm planted $64 \mathrm{~mm}$ deep into both \#3 and \#15 AirPots. Small diameter roots were removed to expose larger structural roots. Roots were deflected up and around trunk by the \#3 container wall, and several roots were wrapping tightly against trunk. A large adventitious root has emerged on the lower-left side of trunk after shifting into the \#15 container. Bottom: Elm planted shallow into the same containers shows straighter roots and fewer roots growing over the flare tangent to trunk. on sites with shallow roots. Stability of trees with roots bent and deflected from growing in containers may be compromised compared to trees with more straight roots; this needs further study.

Some lateral roots emerged as secondary roots from the largest mother roots and grew horizontally just under the substrate surface as Gilman et al. (2006) found with Cathedral Oak. These radially oriented, straight, typically vigorous roots were mixed with roots growing over the flare that were deflected by container walls or grew upward as a result of deep planting (Table 2). It is not clear if these straight roots will become the largest diameter main roots some years later, or whether the original deflected main roots will retain their dominance. Coutts et al. (1999) found in natural settings suppressed, small diameter secondary roots growing from main lateral roots can become dominant in time and take over the role originally occupied by the initial main roots on the tree. This needs more delineation in order to understand how trees become established and stable when planting from containers into urban settings.

Total elm and maple root length over the flare and depth to root flare were not impacted by planting depth into \#3 containers (Table 2) indicating that new roots grew from the buried portion of the stem. These new roots were developing into the root flare when trees were evaluated at the end of the study. Cathedral Oak responded similarly generating new roots on the buried portion of the stem cutting when planted as much as $114 \mathrm{~mm}$ deep into \#3 containers (Gilman et al. 2006). When roots emerged in the current study from the buried portion of the stem in the $64 \mathrm{~mm}$ deep planting treatment, many grew straight to the \#3 container wall resulting in a root system similar to those on trees planted only 13 $\mathrm{mm}$ deep. This explains the similarity in root length over the flare for both planting depths (Table 2). Despite similarity in root length over the flare, percentage of elm trunk circumference with SGRs was greater for trees planted deeply into \#3 compared to shallow planting, but not for maple. Planting deeply apparently encouraged roots to grow close to the trunk by providing substrate over the flare, as Fare (2005) and Gilman et al. (2006) also showed.

\section{Adventitious Root Development}

Adventitious roots on the buried portion of elm and maple trunks on finished \#45 containers were either absent, emerged just under substrate surface, or emerged in several places deeper along the buried stem. Some trees generated one adventitious root, others generated many. Where only one or two were generated on trees planted deeply into \#3 containers, most other roots deflected by container wall were positioned underneath these adventitious roots. In contrast, many deflected roots on the other side of the trunk were growing over the deeper roots that comprised the flare on that side of the tree. This uneven or two-layered root flare has also been reported for field grown trees (Hewitt and Watson 2009). This asymmetrical configuration can make it difficult to decide how to plant the tree.

Magnolia generally did not generate new roots from the buried portion of the stem at any time. Therefore roots near the substrate surface deflecting back toward and around the trunk by the \#3 container wall were positioned over the flare on trees planted $64 \mathrm{~mm}$ deep into \#3 container (Table 2). Unlike elm and maple, magnolia flare was comprised of roots generated primarily at the tip of the cutting soon after the cutting was stuck. Flare was visible at substrate surface on only $7.8 \%$ of deeply planted (64 
$\mathrm{mm}$ ) magnolias (Table 3). This was not surprising because magnolia generates roots primarily from the end of the stem when rooting cuttings, not along the stem according to many propagators (e.g., Todd Gentry, Total Quality Liners, Inc., Groveland FL). Cathedral Oak (Gilman et al. 2006), and probably other trees lose their capacity to generate roots along the buried stem as they grow older. Shallower planted trees into \#3 had fewer roots over the flare because it was higher in the substrate profile and some deflected roots grew under main flare roots.

As shown for Cathedral Oak (Gilman et al. 2006), planting deeply $(64 \mathrm{~mm})$ into \#15 for elm and maple resulted in more serious defects than planting deeply $(64 \mathrm{~mm})$ into \#3 containers (Table 2). The older trees apparently had lost capacity to generate new adventitious roots from the buried portion of the stem. As a result, elm and maple planted deeply into \#15 containers had more roots growing around the trunk, deeper root flare, and more root length over the flare compared to shallow planting. In contrast, magnolia planting depth into \#15 containers had no impact on defects. Magnolia roots were less likely to grow up into substrate placed over the flare as compared to elm and maple when shifted into a \#15. The reason for this is not clear.

\section{Stem Girdling Roots}

Planting deeply into containers may be more problematic than planting deeply into a field nursery because roots in containers are deflected around, up, and back toward the trunk (Gilman et al. 2010a). The result is a container root ball with more root density than a root ball dug from field soil (Harris and Gilman 1993; Gilman and Beeson 1996; Marshall and Gilman 1997). Roots of nursery-sized trees are likely to grow out and away from the trunk on trees planted into field soil (Hewitt and Watson 2009), because there is no container wall to deflect them back over the flare. Another contributing factor that encourages roots to grow down and away from the trunk is the soft soil common to many field nurseries. Roots growing over the flare close to the trunk from deep planted landscape-sized trees (Wells et al. 2006), may result from deflection by sides of planting holes from soil compaction (Gilman et al. 1987; Zisa 1980), which is typical of urban soils.

Planting deeply into Air-Pot containers appeared to encourage development of SGRs. The same occurred when planting deeply into Accelerator containers (Gilman et al. 2006). Worst defects were seen at the position of the \#3 Air-Pot wall because deflected roots were redirected close to the trunk. Despite more defects associated with deeper planting, serious defects occurred even at the shallow planting depths for all three species tested. For example, an average of $59.9 \%$ of the trunk was wrapped with SGRs greater than $5 \mathrm{~mm}$ diameter on maple planted shallow into \#3 containers (Table 2), and $346 \mathrm{~cm}$ of roots greater than $5 \mathrm{~mm}$ diameter were growing over the flare. Both conditions could lead to health problems later (Wells et al. 2006). Root defects should be removed (by pruning) each time the tree is potted to a larger size, even when trees are planted at the appropriate depth in the container. This has been shown to dramatically reduce defects (Gilman et al. 2006; Gilman et al. 2010b).

Most defects were hidden from view because they were found below substrate surface; and presence of a visible root flare was not related to occurrence of root defects (Table 3). Once substrate was removed, defects were clearly visible (Figure 1). Root balls on elm and maple were packed with roots growing in many dif- ferent directions which made it time consuming to remove substrate and roots above root flare. This could have been magnified by retaining trees in \#3 Air-Pot containers for a longer period of time; they were only in for seven months, in this study. More than a few growers (Todd Gentry, pers. comm.) leave trees in this container size for longer. Arborists and others charged with planting trees in this condition will find it time consuming to remove these roots on elm and maple prior to planting.

\section{CONCLUSIONS}

Growers exercising care to position the liner root ball so the top-most root is close to the substrate surface will produce better quality trees than those planting deeper (Figure 2). It appears more problematic to plant deeply into a \#15 container than into a \#3 container size. Lack of root flare was a good indication that trees were planted too deeply into the \#15 container size. Based on results from this study, rooted cuttings of red maple should be positioned so the point where the top-most root emerges from the trunk is within $6 \mathrm{~cm}$ of substrate surface. Magnolia should be positioned as high as possible in the substrate profile because, unlike 'Florida Flame' red maple and Cathedral Oak (Gilman et al. 2006), magnolia roots generally did not grow from the buried portion of the stem. This placed the root flare below many deflected roots which grew over and crossed the flare tangent to the trunk. Allée elm should be positioned as high in the substrate profile as possible to reduce incidence of SGRs which developed when liners were planted deeply into \#3. Root ball surface of \#3 and larger containers should be planted so the point where the top-most main root emerges from the trunk is either at or just below substrate surface. Substrate on the surface along with roots growing over the flare may have to be removed when shifting to a larger container size or into field or landscape soil in order to produce quality root systems.

Growers of container trees can exercise some control over formation of root defects by planting at the appropriate depth; however, even planting shallow at three shifts to larger containers resulted in serious root defects for many trees, especially red maples. Landscape contractors, horticulturists, and arborists also share in the responsibility for helping develop and maintain healthy root systems by instituting root management programs as part of planting and routine maintenance. This strategy could be incorporated into bid specifications. Root systems should be inspected by washing substrate from the surface in order to check for and treat defects.

Acknowledgments: Thanks to www.GreatSouthernTreeConference.org., TREE Fund, and Florida Nursery, Growers and Landscape Association for partial funding of this research.

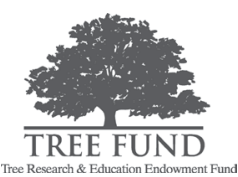

\section{LITERATURE CITED}

Anonymous. 1998. Florida Grades and Standards for Nursery Stock. Florida Department of Agriculture and Consumer Services, Div. of Plant Industry, Gainesville, FL.

Balisky, A.C., P. Salonius, C. Walli, and D. Brinkman. 1995. Seedling roots and forest floor: Misplaced and neglected aspects of British Columbia's reforestation effort? The Forestry Chronicle 71:59-65.

Browne, C., and K. Tilt. 1992. Effects of planting depth on three ornamental trees. Proceedings Southern Nurseryman Association 37:2-4. 
Carvell, K.L., and D.L. Kulow. 1964. Planting depth affects survival and growth of eastern white pine. Journal Forestry 62:735-736.

Coutts, M.P., C.C.N. Nielson, and B.C. Nicoll. 1999. The development of symmetry, rigidity and anchorage of root system of conifers. Plant and Soil 217:1-15

Coutts, M.P., and B.C. Nicoll. 1991. Orientation of lateral roots of trees: 1. upward growth of surface roots and deflection near the soil surface. New Phytologist 119:227-234.

Fare, D. 2005. Should potting depth be a concern for container trees? Proc. Trees and Planting: Getting the Roots Right Conference. Morton Arboretum, Lisle, IL. Nov. 10, 2005.

Gilman, E.F., and R.C. Beeson, Jr. 1996. Nursery production method affects root growth. Journal Environmental Horticulture 14:88-91.

Gilman, E.F., I.A. Leone, and F.B. Flower. 1987. Effect of soil compaction and oxygen content on vertical and horizontal root distribution. Journal Environmental Horticulture 5:33-36.

Gilman, E. F., P. Anderson, and C. Harchick. 2006. Pruning low branches of live oak (Quercus virginiana Mill.) cultivars and seedlings during nursery production: balancing growth and efficiency. Journal Environmental Horticulture 24:201-206.

Gilman, E.F., M. Paz, and C. Harchick. 2010a. Effect of container type on root form of red maple. Journal Environmental Horticulture 28:1-7.

Gilman, E.F., M. Paz, and C. Harchick. 2010b. Root ball shaving improves root systems on seven tree species in containers. Journal Environmental Horticulture 28:13-18.

Goldfarb, B., S.E. Surles, M. Thedford, and F.A. Blazich. 1998. Effects of root morphology on nursery and first-year field growth of rooted cuttings of loblolly pine. Southern Journal of Applied Forestry 22: 231-234

Halter, M.R., and C.P. Chanway. 1993. Growth and root morphology of planted and naturally-regenerated Douglas-fir and lodge-pole pine. Annals Forest Science 50:71-77.

Harris, J.R., and E.F. Gilman. 1993. Production method affects growth and post-transplant establishment of 'East Palatka' holly. Journal American Society Horticulture Science 118:194-200.

Harrington, T.B., and K.D. Howell. 1998. Planting cost, survival, and growth one to three years after establishing loblolly pine seedlings with straight, deformed, or pruned taproots. New Forests 15: 193-204.

Hewitt, A., and G.W. Watson. 2009. Bare root liner production can alter tree root architecture. Journal of Environmental Horticulture 27: 99-104.

Kormanik, P.P. 1986. Lateral root morphology as an expression of sweetgum seedling quality. Forest Science 32:595-604.

Koshi, P.T. 1960. Deep planting has little effect in a wet year. Tree Planter's Notes 11:7.

Lindstrom, A., and G. Rune. 1999. Root deformation in plantations of container-grown Scots pine trees: Effects on root growth, tree stability and stem straightness. Plant and Soil 217:29-37.

Lyons, C.G., Jr., R.E. Byers, and K.S. Yoder. 1983. Influence of planting depth on growth and anchorage of young 'Delicious' apple trees. HortScience 18:923-924.

Lyons, C.G. Jr., R.E. Byers, and K.S. Yoder. 1987. Influence of planting depth on growth of young apple trees. Journal Environmental Horticulture 5:163-164.

Marshall, M.D., and E.F. Gilman. 1997. Production method and irrigation affect root morphology of live oak. Journal Environmental Horticulture 15:84-87.
Owen, J., and H. Stoven. 2008. Searching for the perfect pot. Digger, Mar. pg. 40-45, 57, Oregon Assoc. Nurs. Wilsonville, OR.

Reighard, G.L., G. Howe, and J.W. Hanover. 1985. Effects of chemical weed control and seedling planting depth on survival and growth of aspen. Tree Planter's Notes 36:3-7.

Seiler, J.R., D.J. Paganelli, and B.H. Cazell. 1990. Growth and water potential of j-rooted loblolly and eastern white pine seedlings over three growing seasons. New Forests 4:147-153.

Slocum, G.K., and T.E. Maki. 1956. Some effects of depth of planting upon loblolly pine in the North Carolina piedmont. Journal Forestry $54: 21-25$.

Sparks, D. 2005. Tree setting depth affects wind resistance in pecan. Journal American Pomology Society 59:134-140.

Stout, B.B. 1956. Studies of the root systems of deciduous trees. Black Rock Forest Bulletin. (Harvard Univ.) 15. 45 pp.

VanderSchaaf, C.L., and D.B. South. 2003. Effect of planting depth on growth of open-rooted Pinus elliotii and Pinus taeda seedlings in the United States. South African Forest Journal 198:63-73.

Watson, G.W. 2005. Distinguishing between root system architecture changes and planting too deep. Proc. Trees and Planting: Getting the Roots Right Conference. Morton Arboretum, Lisle, IL. Nov. 10, 2005.

Wells, C., C.E.K.S. Townsend, J.D. Caldwell, D.L. Ham, M. Sherwood, and E.T. Smiley. 2006. Effects of planting depth on landscape tree survival and girdling root formation. Arboriculture \& Urban Forestry 32:305-311.

Zisa, R., H.G. Halverson, and B.B. Stout. 1980. Establishment and early growth of conifers on compact soils in urban areas. USDA Forest Service Research Paper NE No. 451.

Edward F. Gilman (corresponding author)

Professor

Environmental Horticulture Department

University of Florida

Gainesville, FL, U.S.

egilman@ufl.edu.

Chris Harchick

Environmental Horticulture Department

University of Florida

Gainesville, FL, U.S.

Maria Paz

Environmental Horticulture Department

University of Florida

Gainesville, FL, U.S 
Résumé. Une étude a été mise au point pour évaluer l'impact de la profondeur de la plantation par rapport à la morphologie racinaire à l'intérieur des contenants lors de la production en pépinière. Des arbres ont été plantés peu profondément $(13 \mathrm{~mm})$ ou profondément $(64 \mathrm{~mm})$ dans des contenants de dimension \#3 Air-Pot ${ }^{\mathrm{TM}}$, puis transplantés peu profondément $(0 \mathrm{~mm})$ ou profondément $(64 \mathrm{~mm})$ dans des contenants de dimension \#15 Air-Pot ${ }^{\mathrm{TM}}$ avant d'être replantés finalement dans des contenants de dimension \#45 à la même profondeur. Le calibre du tronc était significativement plus gros à la fois chez le magnolia et l'érable rouge plantés peu profondément dans les contenants \#3 et peu profondément par la suite dans les contenants \#15, et ce comparativement à ceux plantés profondément. Cependant, les différences étaient faibles et pouvaient ne pas être significatives pour un producteur. Aucune différence en regard du calibre et de la hauteur parmi les différentes profondeurs de plantation n'a été observée dans le cas de l'orme. La présence de racines principales cerclantes chez l'orme et le magnolia dans les contenants \#45 augmentait avec la profondeur de plantation d'origine dans le contenant \#3. Le réorientation vers le bas de la croissance des racines principales qui comprimaient le pied de la tige en raison de leur pression contre la parois du contenant \#3 est probablement ce qui a contribué à la quantité de racines qui se sont développées au-dessus du pied de la tige. Les systèmes racinaires des érables n'ont pas subi d'impact en relation avec la profondeur de plantation dans les contenants \#3 en raison principalement de l'émergence de racines adventives à partir de la portion enfouie de la tige. La distance entre la surface du substrat et le dessus des racines au niveau du pied de la tige à l'étape finale des contenants \#45 n'était pas influencée par la profondeur de plantation à l'origine dans le contenant \#3, et ce avec chacune des espèces. La plantation d'ormes et d'érables profondément dans les contenants \#15 a produit plus de cas d'étranglement de tronc par des racines cerclantes, un pied d'arbre plus profond et plus de racines qui croissaient au-dessus du pied, et ce comparativement aux sujets plantés moins profondément. La plupart des défauts racinaires observés chez toutes les espèces étaient invisibles parce qu'ils étaient situés sous le niveau du substrat. La présence d'un pied de tige visible n'était pas reliée à l'occurrence de défauts au niveau des racines. Les mottes de terre chez l'orme et l'érable étaient remplis de racines entrelacées entre elles ce qui a exigé beaucoup de temps pour enlever le substrat et les racines au-dessus du pied de la tige. La profondeur de plantation apparaît être la plus cruciale lorsque l'on passe au stade des contenants \#15.

Zusammenfassung. Die Studie wurde konzipert, um den Einfluss der Pflanztiefe in Baumschulcontainern auf die Wurzelmorphologie zu bewerten. Bäume wurden entweder flach $(13 \mathrm{~mm})$ oder tief $(64 \mathrm{~mm})$ in \#3 Air-PotIM Container, danach flach (0 mm) oder tief $(64 \mathrm{~mm})$ in \#15 Air-PotIM Container vor ihrem finalen \#45-Pflanzcontainer in der gleichen Tiefe. Der Stammdurchmesser (Umfang) war bei Magnolien und Ahornen bei flacher Pflanzung in jeweils \#3 und \#15 Container signifikant größer verglichen mit der tiefen Pflanzung. Dennoch waren die Unterschiede klein und mögen für einen Züchter belanglos sein. Für Ulmen wurden keine Unterschiede in Höhe und Umfang bei unterschiedlichen Pflanztiefen gefunden. Bei Ulmen und Magnolien nahm die Anzahl der Würgewurzeln in \#45-Containern zu, wenn die Bäume in \#3-Contain- ern tief gepflanzt wurden. Eine Neuorientierung der Hauptwurzeln, die den Wurzelteller ausmachen, nach unten, beeinflusst durch die Containerwand in \#3, trägt wahrscheinlich zum Wachstuzm von Wurzeln oberhalb des Wurzelkragens bei. Das Wurzelsystem von Ahornen wurde nicht durch die Pflanztiefe in \#3 beeinflusst, hauptsächlich wegen dem Aufkommen von Adventivwurzeln aus den begrabenen Stammteilen. Die Distanz zwischen der Substratoberfläche und dem Wurzelkragen in den \#45 Containern war nicht durch die Pflanztiefe in \#3 Container bei allen Arten beeinflusst. Eine tiefe Pflanzung der Ulmen und Ahorne in \#15 Container führte vermehrt zur Bildung von Würgewurzeln, eines tieferen Wurzelkragens und mehr Wurzelwachstum oberhalb des Wurzelkragens, im Vergleich zur flachen Pflanzung. Die moisten Wurzeldefekte in allen beteiligten Arten waren nicht sichtbar; wir fanden sie unterhalb der Substratoberfläche. Die Anwesenheit von sichtbaren Wurzelkragen war nicht verbunden mit dem Auftreten von Wurzelschäden. Wurzelballen von U1men und Ahornen waren dicht gepackt mit Wurzeln, was es für uns sehr erschwerte, das Substrat und die Wurzeln oberhalb des Wurzelkragens zu entfernen. Die Pflanztiefe schien bei der Verpflanzung in \#15 Container eine besondere Rolle zu spielen.

Resumen. El estudio fue diseñado para evaluar el impacto de la profundidad de plantación en la morfología de la raíz adentro de los contenedores. Los árboles fueron plantados someramente $(13 \mathrm{~mm})$ o profundos $(64 \mathrm{~mm})$ dentro de contenedores \#3 Air-Pot ${ }^{\mathrm{TM}}$; luego someros $(0 \mathrm{~mm})$ o profundos $(64 \mathrm{~mm})$ en \#15 Air-Pot ${ }^{\mathrm{TM}}$ antes de instalarlos en su contenedor final de tamaño \#45 a la misma profundidad. El diámetro del tronco (calibre) fue significativamente mayor en magnolia y arce plantados someros, en contenderos \#3 y en \#15, comparados con los más profundos. Sin embargo, las diferencias fueron pequeñas y pueden no se relevantes para el crecimiento. No se encontraron diferencias en calibre o altura entre profundidades de plantación para olmo. La presencia de raíces estranguladoras en olmo y magnolia, creciendo en contenedores \#45, incrementó con la profundidad de plantación en contenedores \#3. La reorientación descendente de las raíces comprimiendo la corona de la raíz para la pared del contenedor \#3 probablemente contribuyó en la cantidad de raíces creciendo sobre la corona. Los sistemas de raíces del arce no fueron impactados por la profundidad de plantación en \#3, primariamente debido a la emergencia de raíces adventicias de la porción enterrada del tallo. La distancia entre la superficie del sustrato y la corona de la raíz en contenedores finales \#45 no estuvo impactada por la profundidad de plantación en contenedores \#3 para cualquier especie. La plantación de olmo y arce profundamente en \#15 permitió el estrangulamiento del tronco por las raíces, una corona más profunda, y más raíces creciendo sobre la corona de la raíz en comparación a las plantaciones someras. La mayoría de los defectos de las raíces en todas las especies no fueron visibles debido a que fueron encontrados debajo de la superficie del sustrato. La presencia de una corona de la raíz visible no estuvo relacionada con la ocurrencia de defectos en las raíces. Las bolas de raíces en olmo y arce estuvieron empacadas con las raíces, lo cual consumió tiempo para remover el sustrato y raíces de arriba de la corona. La profundidad de plantación parece ser crucial cuando se empleen contenedores \#15. 